\title{
CONGENITAL GRANULAR CELL TUMOUR : A RARE CASE REPORT
}

\section{Sabari Devi}

\section{Waziha Āhmed*}

\section{Associate Professor, Department of Pathology , Gauhati Medical College} and Hospital, Assam.

Senior Resident, Department of Pathology, Gauhati Medical College and Hospital, Assam. *Corresponding Author

ABSTRACT Congenital granular cell tumour/ epulis (CGCE) is a rare benign lesion of the newborn. It was first described in 1871 by Neumann. It usually arises from the alveolar mucosa of neonates and may cause respiratory and feeding problems. The exact histogenesis is unclear. The proposed source of origin includes undifferentiated mesenchymal cells, odontogenic epithelial, pericytes, fibroblasts, smooth muscle cells. Treatment involves surgical excision and and its curative with rare recurrence rate.

KEYWORDS : Epulis, gingival tumor, congenital granular cell epulis, neumann's tumor, infant.

\section{INTRODUCTION :}

Congenital granular cell tumor (CGCT) of the newborn is a rare benign hamartomatous soft-tissue tumor which was first described by Newmann in 1871. ${ }^{1}$ Congenital granular cell tumor (CGCT) has also been referred to as congenital epulis and Neumann tumor. ${ }^{2}$ The Greek word "epulis" means "swelling on the gingiva." ${ }^{3}$ It occurs typically on the masticatory mucosa of the maxillary or mandibular anterior alveolar ridge. It affects the maxilla three times more frequently than the mandible, it has an 8:1 predilection for females. ${ }^{4,5}$ Since its initial report, as of 2002, there had been 216 documented cases, ranging in size from mere millimeters to upwards of $9 \mathrm{~cm}^{2}$. They can interfere with feeding and respiration. The recommended treatment is surgical excision under local or general anaesthetic, although spontaneous regression has been reported. There are no reports of recurrence, even if incomplete margins are excised, malignant change, or future disruption to teeth or gums.

\section{CASE REPORT :}

A one day old female patient weighing around 3500 grams was referred to the department of Paediatric Surgery, Gauhati Medical College and Hospital , Guwahati for evaluation and possible treatment of a soft tissue mass arising from lower gingival margin of oral cavity just to the left of midline. The mass measured $3.6,2.5,0.5 \mathrm{~cm}^{3}$. It was a wide based fleshy mass, pale pink in colour with prominent blood vessels in the surface and a bulbous swelling in the base. The antenatal history of the mother was unremarkable.In view of feeding problems immediate surgery was planned. The mass was removed and submitted for histopathological examination in the department of Pathology, Gauhati Medical College and Hospital, Guwahati.

Histological examination was performed using $3 \mu$ m-thick sections cut from formalin-fixed paraffin-embedded tissue blocks and stained with hematoxylene and eosin.

The microscopy revealed large polyhedral cells containing granular acidophilic cytoplasm as well as small uniform nuclei, with extension to the excisional base of the lesion. Centrally dilated blood vessels were seen. No evidence of malignancy was noted in this this tissue sent for histopathological examination. All microscopic findings appear consistent with that of CGCT.

Staining was negative for S-100 by immunohistochemistry.

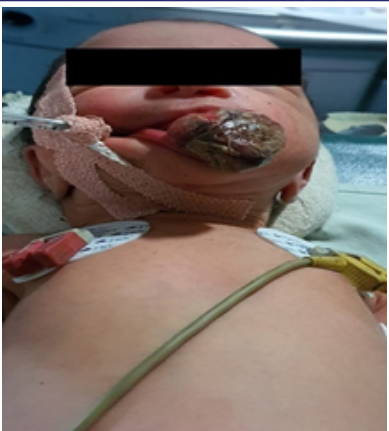

Figl:Clinical photograph showing a pedunculated mass arising from lower gingival margin of oral cavity just to the left of midline.

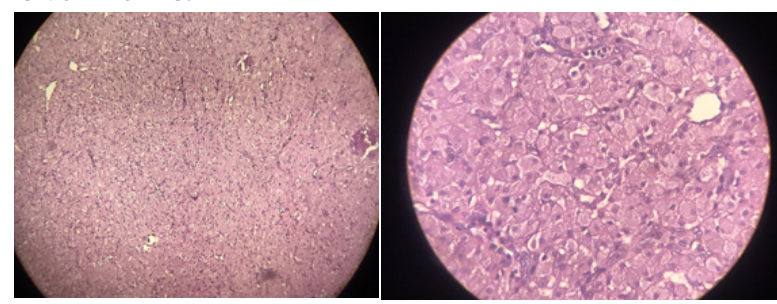

Fig2: H\&E: Tightly packed sheets of large polyhedral cells containing granular acidophilic cytoplasm as well as small uniform nuclei.

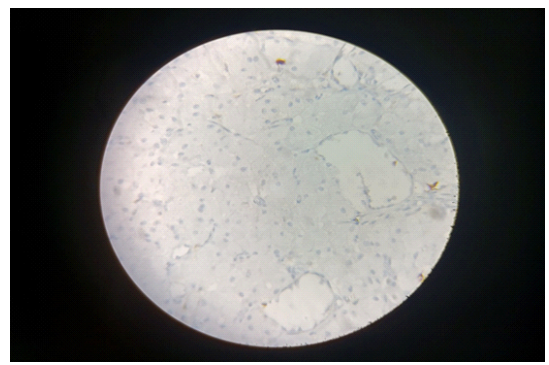

Fig 3 : Negative staining for S-100

\section{DISCUSSION:}

This benign tumor which appears rarely has various names such as congenital epulis (CE), congenital gingival granular cell tumor of the newborn ${ }^{7}$, or Neumann's tumor ${ }^{8}$. Epulis is a Greek word literally meaning "of the gums" and is used to describe a variety of gingival overgrowths. CGCL is a rare, gingival tumor that usually arises in the incisor-canine region of the maxilla (maxilla: mandible ratio is $3: 1$ ). ${ }^{9}$ A female predisposition accounts for eightfold increased incidence above that of males, with no currently known reason, as CGCT has not been found to contain estrogen nor progesterone 
hormonal receptors ${ }^{10,11}$.Though morphologically indistinguishable, its histogenesis is different from adult granular cell tumors. The tumor arises mostly from mucosa over the alveolar ridge, thus interfering with mouth closure and feeding. When multiple, the tumor may cause respiratory obstruction . ${ }^{12}$ Grossly the tumor may present as a firm pedunculated mass arising from alveolar mucosa by means of a stalk. ${ }^{13}$ Antenatal ultrasonographic diagnoses of Congenital epulis have been described in the literature. The earliest reported case was identified by ultrasound in a 31week fetus. ${ }^{14}$ Congenital epulis bears a striking resemblance to adult GCT on light microscopy. It typically presents in newborn females and the characteristic site provides diagnostic clue. However, unlike the adult GCT (myoblastoma), the neonatal counterpart does not have Schwannian origin. This is reflected by its S100 negativity. Various theories have been put forward to explain the controversial origin of CGCT. Most favored theories are gingival epithelial and odontogenic epithelial theories, which support its origin from the mesenchyme. ${ }^{9}$ The mucosal mass is comprised almost entirely of large, rounded and polyhedral, histiocyte-like cells with small, dark, oval nuclei and abundant eosinophilic granular cytoplasm. Lesional cells are usually rounded but may be somewhat spindled. There are vascular channels between granular cells, but fibrous stroma is minimally present and often appears to be completely lacking. The tumor cells extend to the overlying epithelium, which is atrophic and never demonstrates the pseudoepitheliomatous hyperplasia so commonly seen in the granular cell tumor of adults. ${ }^{10,15,16}$ On immunohistochemistry the adult granular cell tumor shows positivity for S100, laminin, nerve growth factor receptor/p75, smooth muscle actin. CGCE (Congenital granular cell epulis) shows positivity for only vimentin, neuron specific enolase. ${ }^{17,18,19}$. Adult granular cell tumor occurs in 30-60 years. It can also be seen in the tongue and other sites ${ }^{18,19}$.

Because of the location of congenital epulis, potential size of the tumor, and risk of interference with breathing and feeding, complete surgical excision is the treatment of choice. ${ }^{19,20}$ Recurrence rarely occurs, and the prognosis is reported to be excellent. ${ }^{21}$ Spontaneous regression has been reported in isolated few cases and may occur even in case of incomplete resection. ${ }^{22}$ However complete resection is curative.

\section{CONCLUSION:}

CGCE is a rare lesion present at birth mostly in female neonates. Prenatal Diagnosis is an important aspect to be considered specifically in this entity. Treatment planning should be based on the prenatal diagnosis, size of the lesion etc.

\section{REFERENCES}

1. Neumann E. An instance of congenital Epulis. Arch Heilkd 1871;12:189-90

2. Reinshagen K, Wessel LM, Roth H, Waag KL. Congenital epulis: a rare diagnosis in paediatric surgery. European journal of pediatric surgery. 2002 Apr; 12(02):124-6.

3. Godra A, D'Cruz CA, Labat MF, Isaacson G. Pathologic quiz case: A newborn with a midline buccal mucosa mass. Congenital gingival granular cell tumor (congenital epulis). Arch Pathol Lab Med 2004;128:585-6

4. Kannan SK, Rajesh R. Congenital epulis - congenital granular cell lesion: $\alpha$ case report. J Indian Soc Pedod Prev Dent 2006; 24:104-106.

5. Koch BL, Myer C 3rd, Egelhoff JC. Congenital epulis. AJNR Am J Neuroradiol 1997; 18:739-741

6. Nakata M, Anno K, Matsumori LT, Sumie M, Sase M, Nakano T, Hara H, Imate Y, Nakamura Y, Kato H. Prenatal diagnosis of congenital epulis: a case report. Ultrasound in Obstetrics and Gynecology: The Official Journal of the International Society of Ultrasound in Obstetrics and Gynecology. 2002 Dec;20(6):627-9.

7. Eghbalian F, Monsef A. Congenital epulis in the newborn, review of the literature and a case report. Journal of Pediatric Hematology/Oncology. 2009 Mar 1;31(3):198-9.

8. Sahu S, Maurya RK, Rao Y, Agarwal A. Multiple congenital epulis in newborn - a rare presentation. Journal of oral and maxillofacial pathology:

\section{JOMFP. 2009 Jul;13(2):78.}

9. Lack EE, Perez-Atayde AR, McGill TJ, Vawter GF. Gingival granular cel tumour of the newborn (congenital epulis): ultrastructural observations relating to histogenesis. Hum Pathol. 1982;13:686-9.

10. JK D, PK S, SNc DA. Congenital granular cell lesion "congenital epulis"Report of a case. J Indian Sot Pedo Prev Dent June. 2004 Jun;22(2):63-7.

11. Lack EE, Worsham GF, Callihan MD, Crawford BE, Vawter GF. Gingival granula cell tumors of the newborn (congenital" epulis"): a clinical and pathologic study of 21 patients. The American journal of surgical pathology. 1981 Jan; $5(1): 37-46$.

12. Parmigiani S, Giordano G, Fellegara G, Brevi B, Magnani C J, Matern F, et al. Neonatal Med 2004;16:55-8.

13. Kannan, S., Rajesh, R. (2006). Congenital epulis-congenital granular cell lesion: A case report. J Indian Soc Pedod Prev Dent 24, 104-6.

14. Kim YD, Kim HJ, Lee NK, Ha WH, Lee CH, Park SE. Congenital epulis: Prenatal ultrasonographic and postnatal MR features with pathologic correlation. Oral Surg Oral Med Oral Pathol Oral Radiol Endod. 2008;106:743-8.

15. Narasimhan K, Arneja JS, Rabah R. Treatment of congenital epulis (granular cell tumour) with excision and gingivoperiosteoplasty. Can J Plast Surg. 2007;15:215-8.

16. Kaiserling E, Ruck P, Xiao JC. Congenital epulis and granular cell tumor: A histologic and immunohistochemical study. Oral Surg Oral Med Oral Pathol Oral Radiol Endod. 1995;80:687-97

17. Bianchi PR, de Araujo VC, Ribeiro JW, Passador-Santos F, Soares de Araujo N, Soares AB. Multiple congenital granular cell epulis: Case report and immunohistochemical profile with emphasis on vascularization. Case Rep Dent 2015;2015:878192

18. Yuwanati M, Mhaske S, Mhaske A. Congenital granular cell tumor - A rare entity. J Neonatal Surg 2015;4:17.

19. Conrad R, Perez MC. Congenital granular cell epulis. Arch Pathol Lab Med 2014;138:128-31.

20. Saki, N., Araghi, S. (2014). Multiple congenital epulis in alveolar ridges of maxilla and mandible in a newborn: a rare case report. Case Rep Otolaryngol 2014, 606985

21. Bang, K., Bodhade, A., Dive, A. (2012). Congenital granular cell epulis of a newborn. Dent Res J. (Isfahan) 9, 136-8.

22. Sakai, V., Oliveira, T., Silva, T., Moretti, A., Santos, C., Machado, M. (2007). Complete spontaneous regression of congenital epulis in a baby by 8 months of age. Int J Paediatr Dent 17, 309-12. 